\title{
Zai Pit Effects on Selected Soil Properties and Cowpea (Vigna unguiculata) Growth and Grain Yield in Two Selected Dryland Regions of Kenya
}

\author{
Sillus O. Oduor*, Nancy W. Mungai, Seth F. O. Owido \\ Department of Crops, Horticulture and Soils, Egerton University, Njoro, Kenya \\ Email: *oduor.1462418@student.egerton.ac.ke
}

How to cite this paper: Oduor, S.O., Mungai, N.W. and Owido, S.F.O. (2021) Zai Pit Effects on Selected Soil Properties and Cowpea (Vigna unguiculata) Growth and Grain Yield in Two Selected Dryland Regions of Kenya. Open Journal of Soil Science, 11, 39-57.

https://doi.org/10.4236/ojss.2021.111003

Received: December 27, 2020

Accepted: January 24, 2021

Published: January 27, 2021

Copyright $\odot 2021$ by author(s) and Scientific Research Publishing Inc. This work is licensed under the Creative Commons Attribution International License (CC BY 4.0).

http://creativecommons.org/licenses/by/4.0/

\section{(c) (i) Open Access}

\begin{abstract}
Erratic rainfall and temperature regimes, strongly affect agricultural productivity. To address the reduction in production, this study assessed the effect of Zai pit depths on selected soil properties and cowpea growth and grain yield. Zai pit technology was tested in two locations falling under Agroecological Zone IV (relatively dry areas) i.e. Machakos in Machakos County and Naivasha in Nakuru County, Kenya, aiming to determine the combined effect of four Zai pit depths and two levels of manure (plots with manure and plots without manure) on selected soil properties, growth and yield of cowpea. Experiment was laid out in split plot arrangement, with manure levels as the main plot factor and Zai pit depths (Flat: $Z_{0}, 30 \mathrm{~cm}: Z_{30}, 45 \mathrm{~cm}: Z_{45}$ and $60 \mathrm{~cm}$ : $Z_{60}$ ) as subplot factor, replicated four times. Cowpea (M66 variety) was used as the test crop. Inorganic nitrogen $\left(\mathrm{N}_{\mathrm{in}}\right)$ and extractable phosphorus $\left(\mathrm{P}_{\mathrm{ex}}\right)$ were significantly $(\mathrm{P}<0.05)$ higher, at $1.37 \mathrm{mg} \cdot \mathrm{kg}^{-1}$ for $\mathrm{N}_{\text {in }}$ and $80.4 \mathrm{mg} \cdot \mathrm{kg}^{-1}$ for $\mathrm{P}_{\mathrm{ex}}$ in Zai pits compared to flat plots which were at $0.91 \mathrm{mg} \cdot \mathrm{kg}^{-1}$ for $\mathrm{N}_{\mathrm{in}}$ and $47.1 \mathrm{mg} \cdot \mathrm{kg}^{-1}$ for $\mathrm{P}_{\mathrm{ex}}$. The values of $\mathrm{N}_{\mathrm{in}}$ and $\mathrm{P}_{\mathrm{ex}}$ also varied depending on depths, with $Z_{45}$ having highest $N_{\text {in }}$ at 1.17 against the least, at 0.89 in the $Z_{0}$, while Pex was highest in $Z_{30}$ at $102.3 \mathrm{mg} \cdot \mathrm{kg}^{-1}$ while $Z_{0}$ having the least $P_{e x}$ of $89.7 \mathrm{mg} \cdot \mathrm{kg}^{-1}$. Generally, crops in Zai pitted plots were larger in diameter $(0.46$ $\mathrm{cm})$ and height $(34.20 \mathrm{~cm})$ than crops in flat plots at $(0.42 \mathrm{~cm})$ and $(18.11 \mathrm{~cm})$ diameter and height respectively. Better performance was observed in yield, with $\mathrm{Z}_{45}$ yielding $853.33 \mathrm{~kg} \cdot \mathrm{Ha}^{-1}$ against $685.0 \mathrm{~kg} \cdot \mathrm{Ha}^{-1}$ in Flat plots in Machakos while $931.66 \mathrm{~kg} \cdot \mathrm{Ha}^{-1}$ in $\mathrm{Z}_{45}$ against $563.33 \mathrm{~kg} \cdot \mathrm{Ha}^{-1}$ from Flat plots in Naivasha. This study demonstrated great potential of Zai pit technology on crop production, as reflected on improved growth and yield of cowpeas. Combining Zai pits with manure increases soil $\mathrm{N}_{\mathrm{in}}, \mathrm{P}_{\mathrm{ex}}$ and is a guarantee of great crop performance in terms of high final yields.
\end{abstract}




\section{Keywords}

Zai Pits, ASALs, Soil Moisture, Dryland Agriculture, Cattle Manure, Inorganic Nitrogen, Extractable Phosphorus

\section{Introduction}

Aridisols are degraded soils, mostly found in relatively dry areas experiencing unreliable rainfall regimes. The low quality of soil and low rainfall minimizes agricultural activities that can be carried out in drylands [1]. For farmers determined to cultivate these soils, they end up producing little that can only support their subsistence till next production season, making it difficult for commercialization. With the current global warming, climate change is inevitable and aridisols continue deteriorating; hence farmers produce less than previously [2]. Reduction in rainfall intensity and duration results in low soil water storage, which reduces soil moisture availability that greatly affects crop production. Water is a critical factor of crop production and before planting, farmers have to consider its source. Some farmers are able to irrigate, while those who cannot afford rely on rainfed crop production, which are proven to reduce production expectations seasonally. Alternatively, soil moisture conservation measures can be adopted, which include the use of Zai pit technology [3].

Zai pit technology uses holes dug in the soil for planting crops to help in soil moisture retention and nutrient/fertilizer maintenance. It is a water harvesting technology [4] that is suitable for areas with unpredictable rainfall and low soil fertility, hence subsequent crop failure. The rain water that would otherwise be lost through runoff is collected in the pits, hence stays longer and is utilized slowly by the plants for various physical, biological and chemical processes [5]. This helps in the reclamation of the drought stricken Arid and Semi-Arid Lands (ASAL) back to their originally productive status [3]. Zai pit technology also helps in reducing waste of fertilizer and manure, and increases their efficiency [1] since instead of being applied in the whole field, the manure is only applied in the pits in which the crops are to be grown. The manure, or any soil treatment, is mixed with the upper $50 \%$ of the soil, which is then returned back to the soil, while the lower $50 \%$ of the soil is piled on the lower side of the pit to trap water in case of any run-off.

The technology, in combination with organic manure, especially Farmyard Manure (FYM), has great influence on selected soil properties [6], which in turn significantly influences growth and development of crops as well as the final yields. Among soil properties influenced are soil inorganic nitrogen and extractable phosphorus. $\mathrm{P}$ and $\mathrm{N}$ are two out of the three major nutrients needed in abundance by the plants throughout, for completion of their growth cycles. Once these nutrients are present in sufficient amount, the growth and development of crops (cowpea) is favoured; hence healthy crops will lead to high grain yields during harvesting. 
Nitrogen makes up almost $80 \%$ of the earth's atmosphere. It is also found in the bodies of all living organisms including plants, taking part in their growth and development. Amount of Inorganic nitrogen $\left(\mathrm{N}_{\mathrm{in}}\right)$ in the soil depends on the $\mathrm{N}$-pools in the soil [7], as well as the amount of added organic/inorganic fertilizers, which add $\mathrm{N}$ in different forms. Organic fertilizers like farmyard manure undergo decomposition to release nutrients, majorly $\mathrm{N}$ and $\mathrm{P}$ that are utilized by plants [8]. Decomposition is the process by which the microorganisms in the soil attack dead biomass, primarily in search or energy and in the process, nutrients are released to the soil. If the applied manure contains higher amounts of Nitrogen than in the surrounding (i.e. C: $\mathrm{N}$ ratio of less than 25:1) [9], $\mathrm{N}$ mineralization takes place, availing it to plants in form of inorganic Nitrogen.

The various inorganic forms of $\mathrm{N}$ soil include ammonium $\left(\mathrm{NH}_{4}^{+}\right)$, nitrite $\left(\mathrm{NO}_{2}^{-}\right)$and Nitrate $\left(\mathrm{NO}_{3}^{-}\right)$[10]. $\mathrm{NH}_{4}^{+}$is the most reduced form and found in anaerobic surroundings while $\mathrm{NO}_{3}^{-}$is the most oxidised form of $\mathrm{N}_{\text {in }}$ and exists in most aerobic environments. They are also very soluble and availing water in the Zai pits makes them readily up taken by plants.

Phosphorus is the next important plant macronutrient element in the soil and it is very important yet very limiting in plant growth and development [11], since it might be present in soil in abundance but not available for plant uptake. This is contributed by its immobility in soils, hence to make it mobile, $\mathrm{pH}$ must be adjusted to favorable ranges of between 6.2 - 6.8 [12]. Therefore, to determine the fraction that is available for growth and development, the extractable phosphorus is always fraction measured in the laboratory [13]. It is available to plants in the form of primary orthophosphate $\left(\mathrm{H}_{2} \mathrm{PO}_{4}^{-}\right)$and Secondary orthophosphate $\left(\mathrm{HPO}_{4}^{2-}\right)[14]$.

In plant tissues, Total Phosphorus $\left(\mathrm{P}_{\mathrm{T}}\right)$ ranges from $0.09 \%$ to $0.6 \%$ [15]. There are limited $\mathrm{P}$ toxicities, while $\mathrm{P}$ below this level lead to deficiencies. Phosphorus deficient produces low yields, and leads to loses to farmers, hence these should be avoided. Deficiency is first observed in the lower old leaves, which display purple or reddish brown along the edges.

Nitrogen is very vital in crop growth, and a healthy plant contains 3\% - 4\% of $\mathrm{N}$ in their above ground tissues [16]. This percentage is greater than any other elements' fractions in the tissues hence its significance. In the tissues, it is measured in form of Total Nitrogen $\left(\mathrm{N}_{\mathrm{T}}\right)$ and it is crucial since it is the main component of chlorophyl [17]. Its presence is also needed since it's a major component of amino acids, which is a building block of proteins. Proteins maintain plants upright since they form structural units in plants cells, hence contributing to the plants' growth in breath (stem) and height. Nitrogen and Phosphorus are also a component of adenosine triphosphate (ATP) [18], a component that assist in energy transfer, hence allowing energy conservation and use in plant cells. Both Phosphorus and Nitrogen are part of the DNA [9], the genetic make-up that permits growth and reproduction. Therefore, $\mathrm{N}$ and $\mathrm{P}$ contribute to the general growth and development of plants and the final yields.

To determine the amount of agronomic $\mathrm{P}$ and $\mathrm{N}$ to add to the soil of optimum 
growth and good yield, soil testing is key [12]. Such nutrients maybe abundant in soil, but inaccessible by plants, since not in their ionic form for uptake by plants. To facilitate nutrient dissolution, water needs to be availed. Zai pits deliver this water through collection from rain water. Nutrients then dissolve to ionic forms, facilitating availability to plants.

Effects on the soil properties finally lead to reciprocating effect on the growth parameters of the crops and to the final yields from the farm. In this experiment, Cowpea (Vigna unguiculata L. Walp) was used as the test crop, and there were significant observations made. Cowpea is an excellent alternative food in the world with its origin in Africa. It is a nutritive source of Vitamin B (89.0\%), Iron (53.6\%), Copper (51.2\%) and Phosphorus (39.2\%) [19]. Zai pit technology has the capability to influence growth parameters like stem diameter, height and final yield of crops.

All parameters are affected proportionately depending on the size of the Zai pits being used. The pits in this experiment had varying depths and were being compared to those plots which the technology was not applied to. Effect of the two different sites (but falling under the same agro-ecological zone) was also investigated. This experiment was carried out in two sites, Machakos and Naivasha, with the aim of determining the combined effect of Zai pit technology and manure levels on selected soil properties, growth and yield of Cowpeas.

\section{Materials and Methods}

\subsection{Site Description}

The study was carried out in two locations, which were Katumani in Machakos county and Naivasha in Nakuru county, Kenya. These two locations, Figure 1,

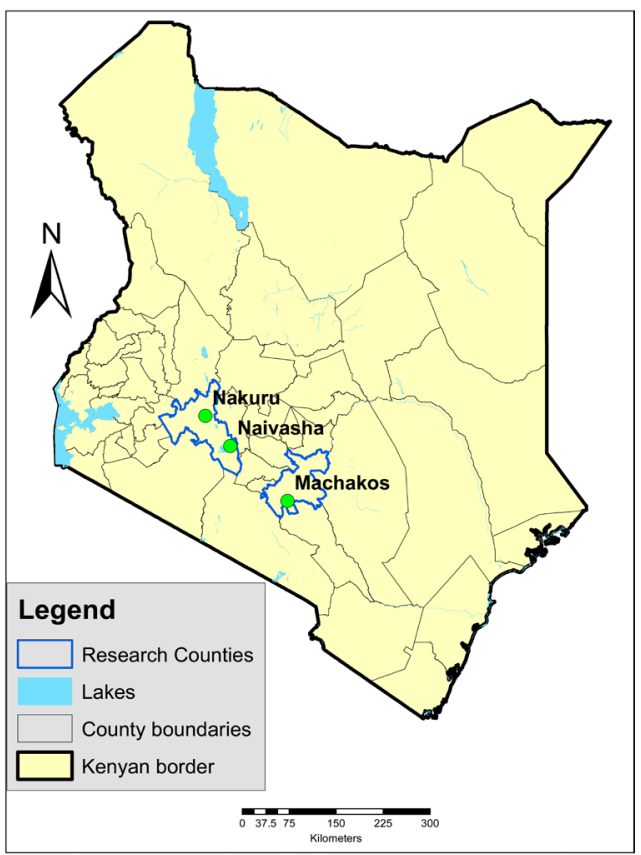

Figure 1. Study sites in selected dryland regions of Kenya. 
have different soil types, with different properties, main one based on the difference in their water holding capacity. This makes them differ in terms of the amount of water that they can avail to the plants due to their infiltration rates. Katumani in Machakos falls under ASAL parts of the Eastern regions of Kenya [20]. It lies in the altitude of 1000 to $2000 \mathrm{~m}$ above the sea level [21] and is located along the longitude $37^{\circ} 14^{\prime} 00^{\prime \prime} \mathrm{E}$ and latitude $1^{\circ} 35^{\prime} 00^{\prime \prime S}$ (GPS). Naivasha in Nakuru County experiences low average rainfall of $677 \mathrm{~mm}$ annually, with a temperatures range of between $9^{\circ} \mathrm{C}$ to $28^{\circ} \mathrm{C}$. It is found in the altitudes of 2086 $\mathrm{m}$ above the sea level. Naivasha lies along the longitudes $36^{\circ} 26^{\prime} 9^{\prime \prime} \mathrm{E}$ and latitudes $0^{\circ} 43^{\prime} 0 " \mathrm{~S}$ (GPS). Both sites fall under similar Agro-ecological zones IV (AEZ), characterized by a lower biennial rainfall regime, with the long rains in the months of March to May while the short rains occur in the months of early October to December. The main soil types in Machakos are aridisols, which are relatively leached and are mostly covered by had grass and shrubs while those in Naivasha Oxisols, mostly common in the tropics.

\subsection{Experimental Design and Treatment}

The experiment was laid out in a Split-Plot Design, where fields "with manure" and "without manure" represented the main plot factors while the sub-plot factor was comprised of Zai pits of different sizes: Without Zai $\left(Z_{0}\right)$ i.e. Flat, Zai pits measuring $60 \times 60 \times 30 \mathrm{~cm}\left(Z_{30}\right)$, Zai pits measuring $60 \times 60 \times 45 \mathrm{~cm}\left(Z_{45}\right)$ and Zai pits measuring $60 \times 60 \times 60 \mathrm{~cm}\left(Z_{60}\right)$. These treatments were replicated four times in both the two study sites.

During the digging of the Zai pits, soil from the pits was piled on the side of the pit for the first 50\%. This represented the top soil, which was then mixed with $1.2 \mathrm{~kg}$ (for Machakos) and $0.6 \mathrm{~kg}$ (Naivasha) of Farmyard Manure for each pit, representing application rates of $9.8 \mathrm{t} / \mathrm{ha}$ and $4.9 \mathrm{t} / \mathrm{ha}$ for the two locations respectively, as recommended after soil fertility analysis of the sample from the respective study locations, followed by cattle manure analysis, which determined their nutrients content. Analysis method was similar to the method described in the "Soil characterization" (below), after which the mixture was returned back into the pits. This was then followed by planting of the Cowpea seeds, where 15 seeds were planted per pit in the pitted plots (containing 12 zai pits) while 3 seeds per hole (in flat plots containing 60 holes). These gave seed density of 120,000 seeds per hectare.

The lower $50 \%$ of the soil was piled on the lower sloping side of the pit and was never returned back to the pit. It remained on the side of the pit to reduce the rate of the run-off during precipitation and hence increase the amount of the rainwater collected in the pits.

\subsection{Soil Characterization}

Before Prior to land preparation, soil samples were taken to the lab for initial characterization. Samples for chemical analysis were collected using Soil auger at 
equidistant points forming a Zigzag at a depth of $15 \mathrm{~cm}$ below the ground surface. These were then mixed in a bucket to form composite samples, after which the representative samples were put in a brown khaki bags for analysis. The samples were airdried in an open-air space for 7 days, after which it was sieved using $<2 \mathrm{~mm}$ sieve. Sieving was then preceded by testing different soil parameters. Soil texture was investigated, through carrying out particle size analysis (PSA) using hydrometer method, as outlined by [22]. Infiltration rate was measured in situ [23] using the Double ring infiltrometer method [24] [25] [26].

Bulk density was determined by the core ring method, where undisturbed samples were collected by driving core rings into the soil up to a depth of $15 \mathrm{~cm}$ using compaction hummer. Then, the core ring was removed with its content (soil). The extending soils on the core sampler were then trimmed carefully with a knife. This was to ensure that the volume of the soil sample fits or is the same to the volume of the core ring.

At the lab, the core rings were placed in the moisture can and weighed together with its content. The core ring plus its content was then place in an oven and dried at $105^{\circ} \mathrm{C}$ for 24 hours, to ensure a constant weight was achieved. After drying, the core ring was then weighed, and the dried weighed recorded. Bulk density was then determined by finding the quotient of the mass of solids and the total volume of soil in the core ring (which has a diameter of $5 \mathrm{~cm}$ and a height of $5 \mathrm{~cm}$ ):

$$
\begin{gathered}
\text { Bulk density of the soil }=\frac{\text { Mass of solids }}{\text { Total volume }} \\
\qquad b=\frac{M s}{V t}
\end{gathered}
$$

While using the same sample(s), mass of water lost was determined by finding the difference between the initial weight of wet soil and the (final) oven-dried weight of soil. This mass was then converted to volume by using the density of water; $1 \mathrm{~g} \cdot \mathrm{ml}^{-1}$ [27] which was then used to determine the Volumetric water content $(\Theta)$ of the soil by dividing volume of lost water by the total volume of soil in the core ring.

$$
\text { Volumetric water content }=\frac{\text { Volume of water }}{\text { Total Volume }}
$$

Soil $\mathrm{pH}$ (water) was determined by a 1:2.5 soil to water ratio, as described by Okalebo et al. [22], Nitrogen was determined according to Kjeldahl method [13], Phosphorus, Potassium, Magnesium, Sodium, Manganese and Calcium were determined using Mehlich I (Double acid) method, according to Mylavarapu et al. [28], while available Iron, Copper and Zinc were extracted in a 1:10 ratio $(\mathrm{w} / \mathrm{v})$ with $0.1 \mathrm{M} \mathrm{HCl}$, which were later determined using AAS (Atomic Absorption Spectrophotometer). Soil carbon was determined calorimetrically according to Okalebo et al. [22].

Soil moisture was monitored weekly using soil neutron probe, Troxler 4300 
model. Here, calibration was first done to enable continuous, steady and accurate measurements specific to soils at each location [29]. Readings were taken weekly throughout the growing season at depth intervals $10 \mathrm{~cm}$ from $0.1 \mathrm{~m}$ up to $1.0 \mathrm{~m}$ deep.

Soil classification and characterization showed that Naivasha had Loamy soils which is well drained, while Machakos had sandy loam soils which is highly drained and very dry at the time of sampling.

At the end of the experiment, soil was sampled for lab analysis, mainly for extractable phosphorus and inorganic nitrogen. Composite samples were obtained from each of the subplots. They were obtained from each of the Zai pits using an auger up to a depth of $20 \mathrm{~cm}$ from the surface of the soil (surface vary from one pit to the other depending on the depth of specific pits), and taken through the drying process as described above. Inorganic $\mathrm{N}$ was then determined using $2 \mathrm{M}$ $\mathrm{KCl}$ as extracting solution, using the ratio 1:5 (soil: solution) according to Estefan et al. [13] while extractable $\mathrm{P}$ was determined by using $5 \mathrm{M}$ sodium bicarbonate $\left(\mathrm{NaHCO}_{3}\right)$ as the extracting solution [13].

\section{Data Analysis}

The data was first tested for normality using "Proc univariate Normal plot", after which it was subjected to the analysis of variance (ANOVA) using proc GLM in Statistical Analysis Software (SAS) version 9.2 [30], followed by mean separation using Tukey's Honestly Significant Difference (HSD) at $\alpha=0.05$.

\section{Results}

\subsection{Changes in Selected Soil Properties as Influenced by Zai Pits Technology and Manure Application}

Difference in soil characteristics were observed at the end of the experiment, with respect to the initial soil characteristics (Table 1), in terms of soil inorganic nitrogen and soil extractable phosphorus. Similar differences were also observed among plots with different manure levels (main plot factor) and different Zai pit sizes (sub-plot factor). Data analysis revealed a significant difference $(\mathrm{P} \leq 0.001)$ due to location (Table 2) in inorganic nitrogen $\left(\mathrm{N}_{\text {in }}\right)$ and extractable phosphorus $\left(\mathrm{P}_{\mathrm{ex}}\right)$ in soil samples analysed at the end of the experiment.

Further, mean separation at $\mathrm{P} \leq 0.05$ shows that manure application had a significant effect in the level of $\mathrm{N}_{\text {in }}$ at the end of the experiment. This was also the case when means of $\mathrm{P}_{\text {ex }}$ were separated $(\mathrm{P} \leq 0.05)$ (Table 2). Zai pit depth, the sub-plot factor was also significant at $\mathrm{P} \leq 0.05$ for the soil $\mathrm{N}_{\mathrm{in}}$. Interaction between Manure and Zai pit technology significantly $(\mathrm{P} \leq 0.05)$ affected soil $\mathrm{N}_{\text {in }}$ as well as soil $\mathrm{P}_{\mathrm{ex}}$ at $\mathrm{P} \leq 0.001$, with higher $\mathrm{N}_{\mathrm{in}}$ from $45 \mathrm{~cm}$ Zai Depth in both two sites (Table 3).

In the experiment, there was a significant improvement in the soil chemical parameters. Inorganic Nitrogen $\left(\mathrm{N}_{\text {in }}\right)$ level in the soil was increased from $0.23 \%$ at onset of the experiment to an overall mean of $0.69 \%$ at the end of the experi- 
ment while total phosphorus $\left(\mathrm{P}_{\mathrm{ex}}\right)$ increased by $29.9 \%$ in Naivasha soils. In Machakos, an upward trend was observed, with an increase of $62.5 \%$ in $\mathrm{N}_{\text {in }}$ and $19.4 \%$ in $\mathrm{P}_{\mathrm{ex}}$. Soil analysis also revealed a significant difference in manure treatments. Plots with manure application revealed a tremendous alteration in soil chemical parameters, e.g. in Table $3, \mathrm{~N}_{\text {in }}$ was constantly higher and significantly different between plots that were applied with manure and those plots that had "No Manure" application, this trend was observed in both Machakos and Naivasha study sites.

Table 1. Soil characterization at Naivasha (Nakuru County) and Machakos (Machakos County) study sites at the beginning of the experiment.

\begin{tabular}{|c|c|c|c|c|}
\hline Analysis & Parameter & Unit & Naivasha & Machakos \\
\hline \multirow{3}{*}{ Physical } & Bulk Density & $\mathrm{g} \cdot \mathrm{cm}^{-3}$ & 1.4 & 1.2 \\
\hline & Infiltration Rate & $\mathrm{cm} \cdot \mathrm{hr}^{-1}$ & 183.7 & 253.1 \\
\hline & Volumetric Water content & $\%$ & 24.1 & 8.2 \\
\hline \multirow{12}{*}{ Chemical } & Total Organic Carbon & $\%$ & 2.5 & 0.7 \\
\hline & $\mathrm{pH}\left(\mathrm{H}_{2} \mathrm{O}\right)$ & & 6.4 & 5.8 \\
\hline & Total Nitrogen & $\%$ & 0.2 & 0.1 \\
\hline & Phosphorus(Mehlich I) & $\mathrm{mg} \cdot \mathrm{kg}^{-1}$ & 284.0 & 39.5 \\
\hline & Potassium & $\mathrm{cmol} \cdot \mathrm{kg}^{-1}$ & 2.8 & 0.8 \\
\hline & Calcium & $\mathrm{cmol} \cdot \mathrm{kg}^{-1}$ & 7.2 & 1.2 \\
\hline & Magnesium & $\mathrm{cmol} \cdot \mathrm{kg}^{-1}$ & 3.8 & 1.9 \\
\hline & Manganese & $\mathrm{cmol} \cdot \mathrm{kg}^{-1}$ & 0.6 & 0.4 \\
\hline & Sodium & $\mathrm{cmol} \cdot \mathrm{kg}^{-1}$ & 1.2 & 0.2 \\
\hline & Iron & $\mathrm{mg} \cdot \mathrm{kg}^{-1}$ & 43.7 & 23.1 \\
\hline & Copper & $\mathrm{mg} \cdot \mathrm{kg}^{-1}$ & 0.8 & 2.5 \\
\hline & Zinc & $\mathrm{mg} \cdot \mathrm{kg}^{-1}$ & 7.1 & 2.6 \\
\hline
\end{tabular}

Table 2. Soil inorganic $\mathrm{N}\left(\mathrm{mg} \cdot \mathrm{kg}^{-1}\right)$ and extractable $\left(\mathrm{mg} \cdot \mathrm{kg}^{-1}\right)$ under various levels of manure application in the two sites.

\begin{tabular}{|c|c|c|c|c|c|c|}
\hline \multirow{2}{*}{ Location } & \multicolumn{3}{|c|}{ Inorganic $\mathrm{N}\left(\mathrm{mg} \cdot \mathrm{kg}^{-1}\right)$} & \multicolumn{3}{|c|}{ Soil Extractable $\mathrm{P}\left(\mathrm{mg} \cdot \mathrm{kg}^{-1}\right)$} \\
\hline & Manure & No manure & $M S D$ & Manure & No manure & $M S D$ \\
\hline Naivasha & $1.80^{\mathrm{a}^{*}}$ & $0.83^{\mathrm{a}+}$ & 0.22 & $52.44^{\mathrm{a} \neq}$ & $41.73^{\mathrm{a}^{4}}$ & 2.87 \\
\hline Machakos & $1.13^{\mathrm{b}^{*}}$ & $0.27^{\mathrm{b}+}$ & 0.24 & $98.25^{\mathrm{b} \neq}$ & $72.56^{\mathrm{b}^{\phi}}$ & 8.33 \\
\hline$M S D$ & 0.34 & 0.26 & & 23.76 & 18.45 & \\
\hline
\end{tabular}

Means with the same letters (within a column) or same symbols (across rows) are not significantly different at $\mathrm{P} \leq 0.05$ (MSD represents Minimum Significant difference). 
Table 3. Interaction of Zai depths $(\mathrm{cm})$ and manure levels and their effect on soil inorganic $\mathrm{N}$.

\begin{tabular}{|c|c|c|c|c|}
\hline \multirow{2}{*}{ Location } & \multirow{2}{*}{ Zai depth $(\mathrm{cm})$} & \multicolumn{2}{|c|}{ Soil Inorganic $\mathrm{N}\left(\mathrm{mg} \cdot \mathrm{Kg}^{-1}\right)$} & \multirow{2}{*}{ MSD } \\
\hline & & Manure & No Manure & \\
\hline \multirow{5}{*}{ Machakos } & 0 & $1.69^{\mathrm{a}^{*}}$ & $0.68^{\mathrm{a}+}$ & 0.17 \\
\hline & 30 & $1.77^{\mathrm{a}^{*}}$ & $0.94^{\mathrm{b}+}$ & 0.32 \\
\hline & 45 & $1.98^{\mathrm{b}^{*}}$ & $0.95^{\mathrm{b}+}$ & 0.14 \\
\hline & 60 & $1.78^{\mathrm{a}^{*}}$ & $0.76^{\mathrm{a}+}$ & 0.10 \\
\hline & $\begin{array}{c}M S D \\
\text { (Minimum Significant difference) }\end{array}$ & 0.11 & 0.12 & \\
\hline \multirow{5}{*}{ Naivasha } & 0 & $1.08^{\mathrm{e}^{*}}$ & $0.20^{\mathrm{at}}$ & 0.20 \\
\hline & 30 & $0.95^{\mathrm{e}^{*}}$ & $0.43^{\mathrm{b}+}$ & 0.29 \\
\hline & 45 & $1.51^{\mathrm{f}^{*}}$ & $0.23^{\mathrm{a}+}$ & 0.12 \\
\hline & 60 & $0.98^{\mathrm{e}^{*}}$ & $0.23^{\mathrm{g}+}$ & 0.04 \\
\hline & $M S D$ & 0.22 & 0.09 & \\
\hline
\end{tabular}

Means with the same letters (within a column) or same symbols (across rows) are not significantly different at $\mathrm{P} \leq 0.05$ (MSD represents Minimum Significant difference).

\subsection{Cowpea Growth Responses to Zai Pits and Manure Application}

Cowpea height and stem diameter were measured 14, 35, 56 and 70 Days after planting (DAP), as shown in Figure 3. Running ANOVA revealed that stem diameter and plant height differed significantly $(\mathrm{P} \leq 0.001)$ across sites (Figure 2), with Naivasha producing both the highest mean pant height of $32.9 \mathrm{~cm}$ as well as the largest stem diameter of $0.51 \mathrm{~cm}$. It is also worth noting that plant heights from Naivasha were all higher than those from Machakos, as observed in Figure 2, where all the heights from Naivasha are above the horizontal line. It was also noted that manure application on both sites influenced cowpeas stem diameter, since the mean diameter (Figure 2) in Machakos was high, at 51.51\% compared to Naivasha, with mean separation using Tukey's HSD revealing a significant difference at $\mathrm{P} \leq 0.05$. ANOVA also revealed a significant difference of mean plant height at $\mathrm{P} \leq 0.01$ due to manure application.

Cowpea stem diameter varied with $Z a i$ depth significantly ( $\mathrm{P} \leq 0.001)$ (Figure 2) while an interaction between Manure application and Zai pit technology had significant effect in plant height at $\mathrm{P} \leq 0.05$. Mean square comparison using $\mathrm{Tu}$ key at $\mathrm{P} \leq 0.05$ also revealed that there was significant difference between Zai pit depths on mean stem diameter, with $45 \mathrm{~cm}$ and $60 \mathrm{~cm}$ depths producing the largest diameter while $0 \mathrm{~cm}$ (flat) and $30 \mathrm{~cm}$ depths producing smallest diameters. Difference was also observed with respect to location, where plants from Naivasha site were significantly taller (Figure 2) than those from Machakos. ANOVA at the same time revealed that time (DAP) of measurement had an effect on the stem diameters (Figure 3(a), Figure 3(c)) and plant heights (Figure 3 (b), Figure 3(d)), noting that there was a continuously upward trend in growth and development of the crops through time. 


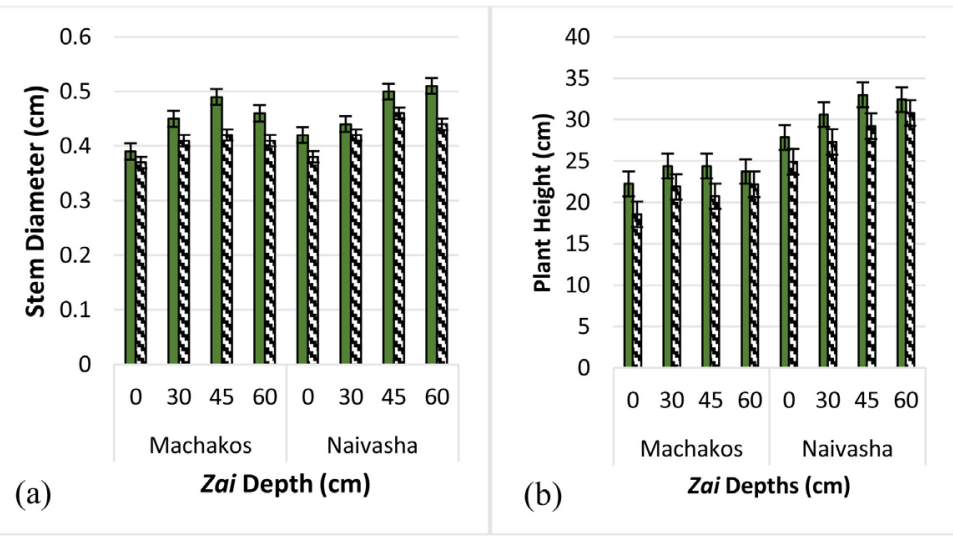

Plus Manure No Manure

Total Average

Figure 2. Zai pits and manure interaction effects on height $(\mathrm{cm})$ and stem diameter $(\mathrm{cm})$ of cowpea in the two study sites (Bars with overlapping standard deviation error bars are not significantly different at $\mathrm{P} \leq 0.05$ ).

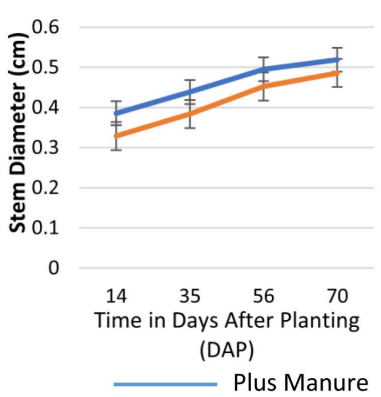

(a)

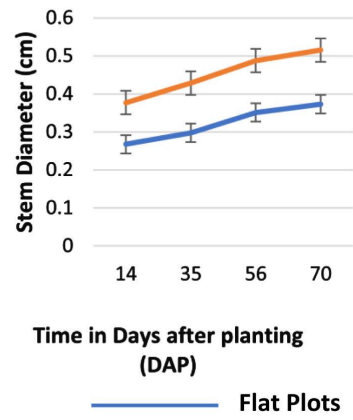

(c)

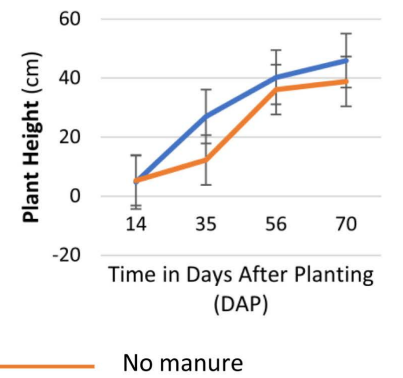

(b)

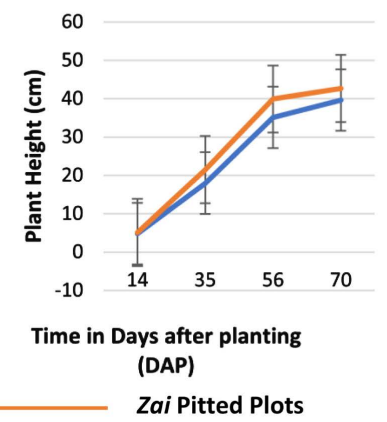

(d)

Figure 3. Effect of interaction between Zai pits, manure and time of measurement on Height $(\mathrm{cm})$ and Stem Diameter $(\mathrm{cm})$ of cowpea.

Plant tissue analysis revealed influence of nutrients in the tissues by the applied treatments. Close observation of Table 4 reveals that location significantly $(\mathrm{P} \leq 0.001)$ influenced both total nitrogen $\left(\mathrm{N}_{\mathrm{T}}\right)$ and total phosphorus $\left(\mathrm{P}_{\mathrm{T}}\right)$. Manure application also had a significant effect on both $\mathrm{N}_{\mathrm{T}}$ and $\mathrm{P}_{\mathrm{T}}$ (Table 4) from the analysis of plant tissues. Further, ANOVA shows that an interaction between location and manure significantly influenced total nitrogen in the plant tissues, based on comparison of means between crops that received manure and crops that had "No Manure" application. 
Table 4. Total N (\%) and total P (\%) in plant tissues as influenced by manure application across locations.

\begin{tabular}{ccccccc}
\hline \multirow{2}{*}{ Location } & \multicolumn{3}{c}{ Plant total N (\%) } & \multicolumn{3}{c}{ Plant total P (\%) } \\
\cline { 2 - 6 } & Manure & No manure & $M S D$ & Manure & No manure & $M S D$ \\
\hline Machakos & $3.46^{\mathrm{a}^{*}}$ & $3.24^{\mathrm{a}+}$ & 0.17 & $0.31^{\mathrm{a} \neq}$ & $0.28^{\mathrm{a}^{\phi}}$ & 0.02 \\
Naivasha & $3.77^{\mathrm{b}^{*}}$ & $3.34^{\mathrm{b}+}$ & 0.09 & $0.25^{\mathrm{b} \neq}$ & $0.27^{\mathrm{b}^{\mathrm{q}}}$ & 0.02 \\
MSD & 0.14 & 0.06 & & 0.01 & 0.01 & \\
\hline
\end{tabular}

Means with the same letters (within a column) or same symbols (across rows) are not significantly different at $\mathrm{P} \leq 0.05$ (MSD represents Minimum Significant difference).

Furthermore, ANOVA revealed a significant difference in the number of pods and pod weight of cowpea at $\mathrm{P} \leq 0.001$ and 100 seed weight and stover weight at $\mathrm{P} \leq 0.05$ (Table 5), which were greatly influenced by manure application.

Zai depth, the sub - plot factor influenced the final yields (Figure 4), since it revealed significance at $\mathrm{P} \leq 0.001$ while an interaction between Manure (Main plot factor) and Zai depth (Sub-plot factor) influenced 100 seed weight ( $\mathrm{P} \leq$ 0.001 ) as well as the stover weight at $\mathrm{P} \leq 0.05$. Flat plots produced low yields from both the two sites, revealing the great roles played by the Zai pits in growth, development and final yield of Cowpea.

\section{Discussion}

Improvement in soil nutrient status can be attributed to the effect brought about by addition of manure, which after decomposition, released nutrients in available forms like ammonium ion $\left(\mathrm{NH}_{4}^{+}\right)$, Nitrite ion $\left(\mathrm{NO}_{2}^{-}\right)$and Nitrate ions $\left(\mathrm{NO}_{3}^{-}\right)$that are available for plant uptake [31]. Secondly, presence of enough soil moisture in the soil (after collection in Zai pits) that dissolve plant nutrients from complex solid substances which existed in the soil to ionic inorganic forms that can be detected and up-taken by plants [16].

Phosphorus is contained in organic forms in bodies of microorganisms found in the manure, as well as in complex metal compounds in the manure [15]. This makes phosphorus not readily available for plant utilization, hence plants might suffer deficiencies even when $\mathrm{P}$ is present in the soil. On favorable conditions i.e. a $\mathrm{pH}$ range of $6.0-7.7$, phosphorus is converted to orthophosphate forms $\left(\mathrm{H}_{2} \mathrm{PO}_{4}^{-}\right.$and/or $\left.\mathrm{HPO}_{4}^{2-}\right)$ that are available to plants, hence ready for uptake by plants [31]. It should be noted that in very acidic soils, $\mathrm{P}$ combines with Iron oxide and/or aluminum oxides while in very alkaline soils (high $\mathrm{pH}$ ), $\mathrm{P}$ combines with Magnesium or Calcium (Ca). These reactions form complex substances that reduce $\mathrm{P}$ availability to plants due to impaired mobility.

In the present study, manure application to the soil may have improved soil particle aggregation that might improve water infiltration in the soil. Zai pits acted as a trough, which trapped the infiltrating water, thereby reducing percolation hence making the water remain within the rooting depth of the crops (Cowpea). This can be affirmed by the results of Adeyemo et al. [32] and reinstated by Kausar et al. [33] that, combining Zai pits and manure application improved the soil water retention, providing enough moisture for plant growth. 


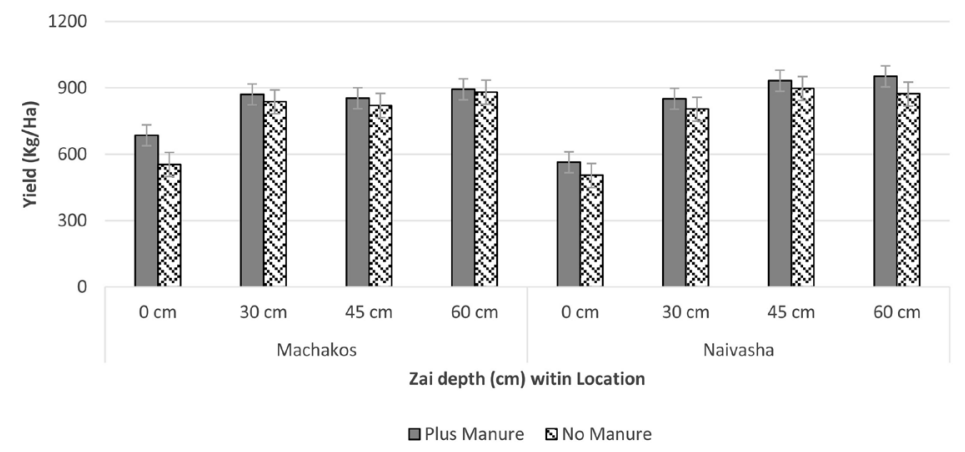

Figure 4. Zai pits depth $(\mathrm{cm})$ and farmyard manure interaction effects on cowpea yields from the two study sites (Bars with overlapping standard deviation error bars are not significantly different at $\mathrm{P} \leq 0.05)$.

Table 5. Farmyard manure application effect on pod number, pod weight, hundred seed weight and stover weight of cowpea from the two study sites.

\begin{tabular}{ccccc}
\hline Manure level & Pod number & Pod weight $(\mathrm{g})$ & 100 seed weight $(\mathrm{g})$ & Stover weight $(\mathrm{g})$ \\
\hline With Manure & $10.65^{\mathrm{a}}$ & $17.73^{\mathrm{b}}$ & $12.25^{\mathrm{b}}$ & $33.82^{\mathrm{a}}$ \\
No Manure & $8.31^{\mathrm{b}}$ & $22.39^{\mathrm{a}}$ & $12.63^{\mathrm{a}}$ & $26.75^{\mathrm{b}}$ \\
MSD & 0.91 & 2.15 & 0.33 & 5.70 \\
\hline
\end{tabular}

Means with the same letter within a column are not significantly different at $\mathrm{P} \leq 0.05$.

Significant difference in inorganic nitrogen and extractable phosphorus in the two locations can be attributed to the difference in the rainfall occurrence in the two locations. Given that the two locations are situated within similar agroecological zones (AEZ IV), climate change over time has resulted in slight difference in weather conditions hence varying rainfall received [3]. This then explains the difference in soil moisture content that resulted into difference in decomposition rates of the applied manure hence the difference in nutrient contents. The higher extractable phosphorus in Naivasha can be attributed to the fact that humid conditions (locations) facilitate rate of decomposition and release of nutrients. Therefore, the rate of release of $\mathrm{P}$ into soil solution for plant utilization was higher in Naivasha site compared to Katumani in Machakos county.

Mean separation revealing difference in soil from plots WITH manure application having higher mean inorganic nitrogen and extractible phosphorus is due to the fact that addition of manure is equivalent to addition of more nutrients into the soil hence this enriches the soil with plant nutrients. These can be supported by Chen et al. [34], as well as Deng et al. [35] who observed that animal manure is a renewable source of plant nutrient elements such as $\mathrm{N}, \mathrm{P}, \mathrm{K}$ and other macronutrients.

Zai pits also influenced soil $\mathrm{N}_{\mathrm{in}}$ and $\mathrm{P}_{\mathrm{ex}}$ that were analyzed at the end of the study, with different Zai pit depths recording different levels of inorganic N. Zai pits at $45 \mathrm{~cm}$ depth recorded highest mean $\mathrm{N}_{\text {in }}$ while flat plots gave the least $\mathrm{N}_{\mathrm{in}}$. This is attributed to the fact that flat plots lacked enough soil water, therefore inadequate soil moisture that reduced the decomposition rate. Incomplete de- 
composition of the FYM manures limits the nutrients release hence limiting the amount of nutrients for plant uptake. Deeper pits $(60 \mathrm{~cm})$ recorded relatively lower soil $\mathrm{N}_{\mathrm{in}}$. This may be due to the fact that collected water was too much such that during infiltration and deep percolation, leaching occurred, hence taking the plant nutrients deep beyond the root zone. This finding can be supported by [36] who stated that high water accumulations prompts water-logging and might result in plant nutrient leaching. Since water logging was observed in some Zai pits in the Naivasha field, this must be true. Low Nin at the $60 \mathrm{~cm} \mathrm{Zai}$ depth can also be attributed to the fact that plant nutrients tend to reduce with increase in depth, making the lower soil horizons be deficient in plant essential nutrients.

Essential nutrients elements available in the soil in the rightful amounts prompt healthy growth and development of the crops. Nutrients uptake by plants is a continuous process that takes place when the nutrients are in the right forms. Nourishment of crops is key for growth and maximum yields. To determine the amount of nutrients in the plant tissues, sampling is done at the right time, for instance in this study, cowpeas tissue samples were done at 45 DAP, just few days before flowering [37] [38]. Tissue analysis for total nitrogen and total phosphorus revealed varying significant levels. Significance due to location effect can be attributed to difference in mineralization processes in the two locations [38]. The lower Machakos $\mathrm{N}_{\mathrm{T}}$ might have been affected by volatilization from soil (in form of $\mathrm{N}_{\mathrm{in}}$ ) due to higher temperatures that favor conversion of $\mathrm{NH}_{4}^{+}-\mathrm{N}$ to ammonia gas that escapes into the atmosphere [39], therefore only few amounts remain in the soil for plant uptake that relatively lowered the tissue $\mathrm{N}_{\mathrm{T}}$.

Total $\mathrm{N}$ and $\mathrm{P}$ are significantly affected by manure application into the soils, in that soils where manure is added reflect a great amount in plant tissues [40]. This is attributed to the fact that after decomposition, the added manure release plant nutrients into the soil, which plus on top of the nutrients that were already in soil initially, hence during uptake, a significant amount are utilized by the crop [36], compared to crops from plots that were not supplied with manure. In some plots where $\mathrm{N}_{\mathrm{T}}$ was high, it was noticed that there was a corresponding higher level of $\mathrm{P}_{\mathrm{T}}$. This is better explained by the findings by Hefner et al. [40] who stated that synergies exists on the uptake process of some plant nutrient, hence $\mathrm{N}$ facilitated uptake and utilization of $\mathrm{P}$ (an immobile nutrient) up to a certain extent.

Plant height and stem diameter of cowpea were greatly affected. This resulted in their significant variation across various treatments. Plants growing under adequate water supply and available nutrient elements in the right amounts are bound to grow healthily and provide highest yields. Soils with higher soil $\mathrm{N}_{\text {in }}$ and $\mathrm{P}_{\mathrm{ex}}$ among other elements boosted the stem diameter and height this explains the significance among observations from plots treated WITH manure and those where manure was not applied. 
Water is critical in various development stages of plants. Various Zai pit depths provided different moisture levels to plants, hence varying plant diameters. Larger stem diameter was observed in deeper Zai pits which stored higher moisture content than in shallow and Flat plots. This can be explained by findings by Kong et al. [41] who stated that stem diameter has a strong correlation with available plant moisture, up to a certain point, just before water-logging that affects "normal" crops' growth and development.

Tentatively, Wan et al. [42], states that xylem and phloem of growing crops increases in size continuously with time, provided that all the growth (both soil and weather conditions) factors are optimal for growth, up to the maximum depending on the crop grown as well as its genetic traits. This explain why the means observed show continuous increase in diameter and height of cowpea from 14 days after planting (DAP) through to after 70 DAP, after which lateral growth in branches was observed. Continuous enlargement in diameter can also be explained by the fact that Zai pits continuously accumulated water hence plants had high chances of converting the provided water into biomass (Water use efficiency) as time goes by.

Results from plots treated with manure application showed a continuously higher mean values in number of pods, 100 seeds weight and stover weight at harvest. This shows that manure resulted in a significant alteration in plants nutrients, and coupled by its effect on soil moisture, crop performance can be enhanced a great deal [43]. This can also be explained by the findings of Astiko et al., [44] that supplying crops with adequate water as well as plant nutrients favors absorption and utilization of the water and plant nutrients which accelerates development of generative organs like branches and higher number of pods which in turn boosts the 100 seeds weigh and the final stover weight at harvest.

The variation in yield data indicates that any change in moisture levels in soil is proportionally reciprocated by plant performance. Manure contains plant nutrients, hence on decomposition, macronutrients like nitrogen and phosphorus are made available for plant uptake. Nitrogen is present in different forms. The inorganic form of $\mathrm{N}$, i.e., ammonium- $\mathrm{N}\left(\mathrm{NH}_{4}^{+}\right)$is immediately available to plants after a short while of application. Therefore, manure influenced plant performance in terms of yield. Same conclusion was also drawn by Goldberg et al. [45] who achieved positive results on short term effects of livestock manure on soil properties. Conditions for better performance were also created by enough soil moisture content which was a result of collection by Zai pits. An interaction of the two led to higher 100 seeds weight as well as stover weight at harvest.

\section{Conclusion}

To increase productivity on the current scarce and low agriculturally productive lands especially in dryland areas, investing in better agricultural inputs and technologies is key. Use of Zai pit technology is one of the interventions that 
have been proven by this research to improve soil $\mathrm{N}$ and $\mathrm{P}$ content, which in turn improved cowpea growth parameters such as stem diameters and height and grain yield. The quality of cowpeas was also improved through enhanced total nitrogen and total phosphorus in the plant tissues. Varying Zai pit depths depending on location and combining it with Farmyard manure guarantees quantity and quality crops and enhanced yields. By using this technology, food insecurity in the ASAL rural areas of Kenya, which are occupied mainly by smallholder farmers, can be eradicated.

\section{Recommendation}

Since ASAL areas experience erratic rainfall regimes, when using Zai pits in the farms, the size of the pits matters a lot. Findings from this research have proven that a pit with $45 \mathrm{~cm}$ depth performs better in terms of moisture retention as well as on plant nutrient delivery, which has seen an increase in stem diameter, height and higher final yields. It is also important to point out that soil moisture boosts yield and general productivity up to a certain level, beyond which no difference is observed. This is evident in Naivasha where pits with $60 \mathrm{~cm}$ depth produced least yields. They could store water for longer, till they become waterlogged for a period of time. Combining Zai pit technology with manure application guarantees highest yields since they provide nutrients, which is evident by improved inorganic nitrogen and extractable phosphorus in soils, as well as improving soil structure that aids in boosting soil moisture availability at the root zone. These in turn brought about higher $\mathrm{N}_{\mathrm{T}}$ and $\mathrm{P}_{\mathrm{T}}$ in cowpeas tissues, thereby contributing to significance in yields from plots that contained Zai pit technology. We also recommend that this research should be carried out over more than two seasons to assess how often manure should be added based on duration of residual effect of the applied manure.

\section{Acknowledgements}

Gratitude to The Centre of Excellence in Sustainable Agriculture and Agribusiness Management (CESAAM) Egerton University, for providing funds for this research project. We are thankful to the entire management of Kenya Agricultural and Livestock Research Organization (KALRO) for their assistance: Provision of soil Neutron probe, laboratory for soil and plant sample analysis and provision of fields for the experimental trials. We also acknowledge Mr. Tabere Denis Bidai for generation of the study site map using ArcGIS version 10.5.

\section{Conflicts of Interest}

The authors declare no conflicts of interest regarding the publication of this paper.

\section{References}

[1] Naba, W., Moges, A. and Gebremichael, A. (2020) Evaluating the Effect of In-Situ 
Rainwater Harvesting Techniques on Maize Production in Moisture Stress Areas of Humbo Woreda, Wolaita Zone, Southern Ethiopia. International Journal of Agricultural Research, Innovation and Technology, 10, 71-79.

https://doi.org/10.3329/ijarit.v10i1.48096

[2] Mwangi, P., Okelo, O.W., Kamande, K.F. and Mwende, M.J. (2020) A Climate-Smart Agriculture Approach Using Double Digging, Zai Pits and Aquacrop Model in Rain-Fed Sorghum Cultivation at Wiyumiririe Location of Laikipia County, Kenya. Africa Journal of Physical Sciences, 4, 23-53.

[3] Kimaru-Muchai, S.W., Ngetich, F.K., Baaru, M. and Mucheru-Muna, M.W. (2020) Adoption and Utilization of Zai Pits for Improved Farm Productivity in Drier Upper Eastern Kenya. Journal of Agriculture and Rural Development in the Tropics and Subtropics, 121, 13-22.

[4] Partey, S.T., Zougmoré, R.B., Ouédraogo, M. and Campbell, B.M. (2018) Developing Climate-Smart Agriculture to Face Climate Variability in West Africa: Challenges and Lessons Learnt. Journal of Cleaner Production, 187, 285-295. https://doi.org/10.1016/j.jclepro.2018.03.199

[5] Serah, K. (2017) Zai Pits and Integrated Soil Fertility Management Enhances Crop Yields in the Dry Parts of Tharaka-Nithi County, Kenya. University of Nairobi Repository, Nairobi.

[6] Pocknee, S. and Summer, E. (1997) Cation and Nitrogen Contents of Organic Matter Determines Its Liming Potential. Soil Science Society of America Journal, 61, 86-92. https://doi.org/10.2136/sssaj1997.03615995006100010014x

[7] Omara, P., Aula, L., Oyebiyi, F.B., Eickhoff, E.M., Carpenter, J. and Raun, W.R. (2020) Biochar Application in Combination with Inorganic Nitrogen Improves Maize Grain Yield, Nitrogen Uptake, and Use Efficiency in Temperate Soils. Agrono$m y, 10,1241$. https://doi.org/10.3390/agronomy10091241

[8] Yang, X., Geng, J., Huo, X., Lei, S., Lang, Y., Li, H. and Liu, Q. (2020) Effects of Different Nitrogen Fertilizer Types and Rates on Cotton Leaf Senescence, Yield and Soil Inorganic Nitrogen. Archives of Agronomy and Soil Science, 1-14. https://doi.org/10.1080/03650340.2020.1799983

[9] Paul, E.A. (2014) Soil Microbiology, Ecology and Biochemistry. Academic Press, Cambridge, 35-107.

[10] Clunes, J., Deltedesco, E., Pinochet, D., Mentler, A., Inselsbacher, E. and Keiblinger, K.M. (2020) Inorganic Nitrogen Diffusion in Undisturbed Volcanic Soils during Continuous Drying-Rewetting Cycles. Journal of Plant Nutrition and Soil Science.

[11] Das, S.K. and Das, S.K. (2020) Influence of Phosphorus and Organic Matter on Microbial Transformation of Arsenic. Environmental Technology \& Innovation, 19, Article ID: 100930. https://doi.org/10.1016/j.eti.2020.100930

[12] Hu, B., Bourennane, H., Arrouays, D., Denoroy, P., Lemercier, B. and Saby, N.P. (2020) Developing Pedotransfer Functions to Harmonize Extractable Soil Phosphorus Content Measured with Different Methods: A Case Study across the Mainland of France. Geoderma, 381, Article ID: 114645.

https://doi.org/10.1016/j.geoderma.2020.114645

[13] Estefan, G., Sommer, R. and Ryan, J. (2013) Methods of Soil, Plant, and Water Analysis: A Manual for the West Asia and North Africa Region. Third Edition, International Center for Agricultural Research in the Dry Areas (ICARDA), Beirut, 84-105.

[14] Weihrauch, C., Schupp, A., Söder, U. and Opp, C. (2020) Could Oxalate-Extractable Phosphorus Replace Phosphorus Fractionation Schemes in Soil Phosphorus Pros- 
pections?-A Case Study in the Prehistoric Milseburg Hillfort (Germany). Geoarchaeology, 35, 98-111. https://doi.org/10.1002/gea.21760

[15] Carver, R.E., Nelson, N.O., Roozeboom, K.L. and Kirkham, M.B. (2020) Species and Termination Method Effects on Phosphorus Loss from Plant Tissue. Journal of Environmental Quality, 49, 97-105. https://doi.org/10.1002/jeq2.20019

[16] Akhtar, K., Wang, W., Ren, G., Khan, A., Enguang, N., Khan, A. and Wang, H. (2020) Straw Mulching with Inorganic Nitrogen Fertilizer Reduces Soil $\mathrm{CO}_{2}$ and $\mathrm{N}_{2} \mathrm{O}$ Emissions and Improves Wheat Yield. Science of the Total Environment, 741, 140488. https://doi.org/10.1016/j.scitotenv.2020.140488

[17] Arsic, M., Le Tougaard, S., Persson, D.P., Martens, H.J., Doolette, C.L., Lombi, E. and Husted, S. (2020) Bioimaging Techniques Reveal Foliar Phosphate Uptake Pathways and Leaf Phosphorus Status. Plant Physiology, 183, 1472-1483. https://doi.org/10.1104/pp.20.00484

[18] Zhang, Y., Qi, G., Wang, B., Wang, D. and Jin, Y. (2020) Single-Cell Adenosine Triphosphate Content Monitoring during Hyperthermia Cell Death by Using Plasmonic Fluorescent Nanoflare. Analytical Chemistry, 92, 3882-3887.

https://doi.org/10.1021/acs.analchem.9b05366

[19] Mndzebele, B., Ncube, B., Fessehazion, M., Mabhaudhi, T., Amoo, S., du Plooy, C., Modi, A., et al. (2020) Effects of Cowpea-Amaranth Intercropping and Fertiliser Application on Soil Phosphatase Activities, Available Soil Phosphorus, and Crop Growth Response. Agronomy, 10, 79. https://doi.org/10.3390/agronomy10010079

[20] Lillian, N. and Mutiso, J. (2019) Determinants of Sustainability of Water Projects at Machakos County in Kenya. Journal of Entrepreneurship and Project Management, 4, 118-138.

[21] Mathuku, M.J. (2016) Climate Change and Variability and the Possible Impacts in Machakos County. A Research Project Presented in Partial Fulfilment of the Requirements for Bachelor of Science Degree (BSc) in Meteorology, University of Nairobi, Nairobi.

[22] Okalebo, J.R., Gathua, K.W. and Woomer, P.L. (2002) Laboratory Methods of Soil and Plant Analysis: A Working Manual Second Edition. Sacred Africa, Nairobi, 21.

[23] Pal, B. (2018) Determination of Hydraulic Properties of Locally Available Soils Using Double Ring Infiltrometer. Doctoral Dissertation in Soil and Water Engeneering.

[24] Swartzendruber, D. and Olson, T.C. (1961) Model Study of the Double-Ring Infiltrometer as Affected by Depth of Wetting and Particle Size. Soil Science, 92, 219-225. https://doi.org/10.1097/00010694-196110000-00001

[25] Bodhinayake, W. and Cheng Si, B. (2004) Near-Saturated Surface Soil Hydraulic Properties under Different Land Uses in the St Denis National Wildlife Area, Saskatchewan, Canada. Hydrological Processes, 18, 2835-2850.

https://doi.org/10.1002/hyp.1497

[26] Lai, J. and Ren, L. (2007) Assessing the Size Dependency of Measured Hydraulic Conductivity Using Double-Ring Infiltrometers and Numerical Simulation. Soil Science Society of America Journal, 71, 1667-1675. https://doi.org/10.2136/sssaj2006.0227

[27] Mylavarapu, R.S., Sanchez, J.F., Nguyen, J.H. and Bartos, J.M. (2002) Evaluation of Mehlich-1 and Mehlich-3 Extraction Procedures for Plant Nutrients in Acid Mineral Soils of Florida. Communications in Soil Science and Plant Analysis, 33, 807-820. https://doi.org/10.1081/CSS-120003067

[28] Johnson, B., Thomas, M. and Barrash, W. (2013) Neutron Installation, Calibration 
and Data Treatment at the Boise Hydrological Research Site. Technical Report BSU CGISS 13-01.

[29] Gomez, K.A. and Gomez, A.A. (1984) Statistical Procedures for Agricultural Research. John Wiley \& Sons, Hoboken, 84-135.

[30] Mangale, N., Muriuki, A., Kathuku-Gitonga, A.N., et al. (2016) Field and Laboratory Research Manual for Integrated Soil Fertility Management in Kenya. Kenya Soil Health Consortium, Kalro Kabete.

[31] Beck, M.A., Zelazny, L.W., Daniels, W.L. and Mullins, G.L. (2004) Using the Mehlich-1 Extract to Estimate Soil Phosphorus Saturation for Environmental Risk Assessment. Soil Science Society of America Journal, 68, 1762-1771. https://doi.org/10.2136/sssaj2004.1762

[32] Adeyemo, A.J., Akingbola, O.O. and Ojeniyi, S.O. (2019) Effects of Poultry Manure on Soil Infiltration, Organic Matter Contents and Maize Performance on Two Contrasting Degraded Alfisols in Southwestern Nigeria. International Journal of Recycling of Organic Waste in Agriculture, 8, 73-80. https://doi.org/10.1007/s40093-019-0273-7

[33] Kausar, R., Akram, M.I., Choudhary, M.I., Malik, A., Zahid, A.R. and Ali, B. (2020) Soil Moisture Retention and Rainfed Wheat Yield Variations by the Addition of Gypsum and Green Manure. Journal of Soil Science and Environmental Management, 11, 6-16. https://doi.org/10.5897/JSSEM2019.0780

[34] Chen, H., Awasthi, S.K., Liu, T., Duan, Y., Ren, X., Zhang, Z., Awasthi, M.K., et al. (2020) Effects of Microbial Culture and Chicken Manure Biochar on Compost Maturity and Greenhouse Gas Emissions during Chicken Manure Composting. Journal of Hazardous Materials, 389, Article ID: 121908.

https://doi.org/10.1016/j.jhazmat.2019.121908

[35] Deng, Y., Zhang, T., Clark, J., Aminabhavi, T., Kruse, A., Tsang, D.C., Ren, H., et al. (2020) Mechanisms and Modelling of Phosphorus Solid-Liquid Transformation during the Hydrothermal Processing of Swine Manure. Green Chemistry, 22, 5628-5638. https://doi.org/10.1039/D0GC01281E

[36] Luo, L., Zhang, Y. and Xu, G. (2020) How Does Nitrogen Shape Plant Architecture? Journal of Experimental Botany. https://doi.org/10.1093/jxb/eraa187

[37] Cataldo, D.A., Schrader, L.E. and Youngs, V.L. (1974) Analysis by Digestion and Colorimetric Assay of Total Nitrogen in Plant Tissues High in Nitrate 1. Crop Science, 14, 854-856. https://doi.org/10.2135/cropsci1974.0011183X001400060024x

[38] López-Calderón, M.J., Estrada-Ávalos, J., Rodríguez-Moreno, V.M., MauricioRuvalcaba, J.E., Martínez-Sifuentes, A.R., Delgado-Ramírez, G. and Miguel-Valle, E. (2020) Estimation of Total Nitrogen Content in Forage Maize (Zea mays L.) Using Spectral Indices: Analysis by Random Forest. Agriculture, 10, 451. https://doi.org/10.3390/agriculture10100451

[39] Beiyuan, J., Fang, L., Chen, H., Li, M., Liu, D. and Wang, Y. (2020) Nitrogen of EDDS Enhanced Removal of Potentially Toxic Elements and Attenuated Their Oxidative Stress in a Phytoextraction Process. Environmental Pollution, 268, Article ID: 115719. https://doi.org/10.1016/j.envpol.2020.115719

[40] Hefner, M., Canali, S., Willekens, K., Lootens, P., Deltour, P., Beeckman, A., Kristensen, H.L., et al. (2020) Termination Method and Time of Agro-Ecological Service Crops Influence Soil Mineral Nitrogen, Cabbage Yield and Root Growth across Five Locations in Northern and Western Europe. European Journal of Agronomy, 120, Article ID: 126144. https://doi.org/10.1016/j.eja.2020.126144

[41] Kong, W., Jin, H., Goff, V.H., Auckland, S.A., Rainville, L.K. and Paterson, A.H. 
(2020) Genetic Analysis of Stem Diameter and Water Contents to Improve Sorghum Bioenergy Efficiency. G3: Genes, Genomes, Genetics, 10, 3991-4000. https://doi.org/10.1534/g3.120.401608

[42] Wan, Y., Yu, P., Li, X., Wang, Y., Wang, B., Yu, Y. and Wang, S. (2020) Seasonal Pattern of Stem Diameter Growth of Qinghai Spruce in the Qilian Mountains, Northwestern China. Forests, 11, 494. https://doi.org/10.3390/f11050494

[43] Uddin, F.J., Mira, H.H., Sarker, U.K. and Akondo, M.R.I. (2020) Effect of Variety and Boron Fertilizer on the Growth and Yield Performance of French Bean (Phaseolus vulgaris L.). Archives of Agriculture and Environmental Science, 5, 241-246. https://doi.org/10.26832/24566632.2020.050302

[44] Astiko, W., Ernawati, N.M.L. and Silawibawa, I.P. (2020) The Effect of Plant Density at the Maize-Soybean Intercropping Pattern Inoculated with Mycorrhizae and Organic Fertilizer to the Growth and Yield in Dry Land North Lombok, Indonesia. International Journal of Innovative Science and Research Technology. https://doi.org/10.38124/IJISRT20JUL311

[45] Goldberg, N., Nachshon, U., Argaman, E. and Ben-Hur, M. (2020) Short Term Effects of Livestock Manures on Soil Structure Stability, Runoff and Soil Erosion in Semi-Arid Soils under Simulated Rainfall. Geosciences, 10, 213.

https://doi.org/10.3390/geosciences10060213 